\title{
Peran Orang Tua dalam Membentuk Akhlak Anak Sejak Dini
}

\section{Nur Lailatul Fitri}

STAI Al Hikmah Tuban

Email: ila.elfitri88@gmail.com

\begin{abstract}
Parents have an important role in shaping the moral valuess of children. But busyness becomes the main reason parents do not have enough time to educate children, consequently education is left entirely to the teacher. The cultivation of moral values from an early childhood becomes an important point to face the moral decadence that occurs, where the family has a major role in shaping the morals of children. The purpose of writing this article is to know the role of parents in shaping the morality of children in Gesik, Gesikharjo village RT / RW $002 / 002$. The methodology of writing this article is descriptive qualitative. Data were collected through observation, interview and documentation, then analyzed by data reduction, data presentation and conclusion. The result of this research is parents in Gesik, Gesikharjo village RT / RW 002/002 who have quality togetherness with children and who apply democratic parenting, they can shape the children's behaviour rich with moral values.
\end{abstract}

Keywords: moral values, parenting, early childhood. 


\section{PENDAHULUAN}

Tujuan pendidikan yang tertuang dalam UU Sisdiknas no. 20 tahun 2003 tampaknya perlu dikaji lagi. Peserta didik yang diharapkan mampu mengembangkan kekuatan spiritual, pengendalian diri, berkepribadian cerdas serta berakhlakul karimah, nyatanya tidak kita lihat dalam proses belajar mengajar di sekolah. Aspek kognitif lebih ditekankan daripada nilai moral/akhlak. Hal ini disadari atau tidak disebabkan karena berubahnya orientasi masyarakat dari belajar untuk mencari ilmu berubah menjadi belajar untuk mencari kerja. Akibatnya pendidikan akhlak tidak terintegrasi pada pribadi anak.

Krisis akhlak menjadi persoalan besar bangsa Indonesia saat ini. Bila kita membaca dan melihat tayangan-tayangan di media massa, banyak kita jumpai kasus-kasus kekerasan seperti pembunuhan, tawuran yang melibatkan lembaga pendidikan, dan yang lebih miris lagi kasus perzinaan yang melibatkan anak dibawah umur tak luput dari pemberitaan.

Tak bisa dipungkiri kemerosotan akhlak yang terjadi adalah akibat dari pengaruh keluarga dan lingkungan sejak kecil. Penanaman akhlak sejak usia dini menjadi poin penting untuk menghadapi dekadansi akhlak yang terjadi, dimana keluarga mempunyai peran utama dalam membentuk akhlak anak.

Permasalahannya sekarang, tidak semua orang tua paham akan pentingnya pendidikan akhlak dalam keluarga. Kebutuhan hidup yang semakin tinggi mengharuskan kedua orang tua untuk bekerja. Sementara pendidikan akhlak diserahkan sepenuhnya kepada guru. Fenomena inilah yang menjadi kajian dalam penelitian ini. Adapun fokus penelitian ini adalah pada peran orang tua dalam menanamkan akhlak anak di dusun Gesik RT. 002 RW. 001 desa Gesikharjo dengan sub fokus yang diteliti adalah perlakuan orang tua terhadap aktivitas anak serta perilaku/ akhlak anak dalam keseharian. Indikator dari pencapaian sementara pendidikan akhlak anak tersebut adalah : 1) Beribadah, seperti tata cara pelaksanaan sholat beserta bacaan-bacaannya, hafalan surat-surat pendek 
dan do'a sehari-hari. 2) Sikap sopan santun terhadap orang lain. 3) Menjaga kebersihan

\section{DISKUSI}

\section{Pendidikan Akhlak dan Urgensinya}

Akhlak adalah bentuk jama' dari khuluq yang berarti perangai, karakter, tingkahlaku dan tabi'at. Menurut Ibnu Maskawaih akhlak adalah keadaan jiwa yang mengajak seseorang untuk melakukan perbuatan tanpa dipikirkan dan diperhitungkan sebelumnya (Ibnu Maskawih, (1934: 20). Senada dengan Ibnu Maskawaih, Imam Ghazali dalam kitab Ihya' Ulumuddin juga menjelaskan bahwa akhlak adalah suatu sifat yang tertanam dalam jiwa seseorang yang dari sifat tersebut muncul suatu perbuatan dengan mudah tanpa perlu pertimbangan (Imam Ghazali: 56). Dengan kata lain, akhlak adalah keadaan seseorang yang membuat orang tersebut melakukan sesuatu secara spontanitas.

Dalam diri manusia terdapat 2 potensi, yakni potensi untuk melakukan kebaikan dan potensi untuk melakukan keburukan. Keduanya merupakan suatu proses, dari baik ke buruk, buruk menjadi baik, atau tetap selalu dalam kebaikan. Proses tersebut akan berhenti pada suatu titik yang kemudian membentuk kecenderungan manusia. Agar manusia dapat bertahan dalam kecenderungan yang baik maka diperlukan pendidikan akhlak.

Adapun tujuan pokok dalam pendidikan akhlak adalah agar setiap orang berbudi pekerti, bertingkah laku, berperangai / beradat istiadat yang sesuai dengan syariat Islam. Oleh karenanya pendidikan akhlak mendapat perhatian paling utama dalam Islam. Sebagaimana kita lihat bahwa misi kerasulan Nabi Muhammad adalah untuk menyempurnakan akhlak. Untuk mencapai tujuan dari pendidikan akhlak tersebut, diperlukan adanya keteladanan dan pembiasaan, sebab akhlak bukanlah suatu pengetahuan yang harus diajarkan 
melainkan harus ditanamkan melalui proses imitasi (keteladanan).

\section{Peran Orang Tua dalam Pembentukan Akhlak Anak}

Keluarga merupakan tempat tumbuh kembang anak, dimana ia akan mendapat berbagai pengaruh langsung terutama saat masa-masa emas anak. Orang tua, terutama ibu akan memberikan pengalaman pertama dalam kehidupan anak, yang mana pengalaman tersebut akan selalu memberikan dampak yang istimewa dan berarti dalam kehidupannya dimasa mendatang. Dalam hadis nabi disebutkan, "al-umm madrasatul uulaa...". Ibu adalah madrasah (tempat belajar) pertama bagi anak-anaknya.

Islam memandang bahwa ujung tombak dari kemakmuran suatu masyarakat, bangsa maupun negara adalah akhlakul karimah. Tanpa adanya akhlak yang baik, dalam masyarakat tidak akan tercipta ketenangan dan kedamaian, yang ada kriminalitas terjadi dimana-mana. Akhlak yang baik akan membentengi masing-masing individu dari pengaruh buruk untuk menjadi pribadi yang unggul. Dengan demikian peran orang tua sangat dibutuhkan dalam pembentukan akhlak anak. Peran tersebut bertujuan agar anak dapat tumbuh dan berkembang seauai dengan usianya, mampu bersosialisasi dan menjadi pribadi yang sholih (Padjrin, 2016: 5).

Sayangnya sampai saat ini belum ada 'kurikulum'yang bisa digunakan sebagai acuan pendidikan dalam keluarga. Menurut Dadang sebagaimana yang dikutip Suyatno, bahwa anak yang dibesarkan dalam keluarga yang harmonis dan keluarga yang tidak harmonis memiliki resiko yang berbeda. Resiko anak mengalami gangguan kepribadian menjadi berkepribadian anti sosial dan berperilaku menyimpang lebih besar berasal dari keluarga tidak harmonis dibandingkan dengan anak yang berasal dari keluarga harmonis.

Adapun kriteria keluarga tidak harmonis yang dirangkum Slamet Suyanto (2005: 4), sebagai berikut. 
1. Keluarga tidak utuh

2. Kesibukan orang tua

3. Hubungan interpersonal keluarga yang tidak baik

4. Gangguan fisik / mental dalam keluarga

5. Substansi kasih sayang yang cenderung ke bentuk materi daripada psikologis

6. Orang tua jarang di rumah

7. Hubungan ayah ibu yang tidak sehat

8. Sikap orang tua yang acuh pada anak

9. Sikap kontrol yang kurang konsisten

10. Kurang stimulus kognitif dan sosial.

Pada dasarnya kriteria-kriteria tersebut diatas dapat diminimalisir resikonya dengan memberikan pengasuhan yang berkualitas. Kualitas tersebut mengacu pada nilai stimulasi tumbuh kembang yang diberikan orang tua kepada anak dalam waktu-waktu kebersamaannya, yakni bisa dilalui dengan berbagai aktivitas pemberian stimulasi atau penyediaan kesempatan belajar sesuai dengan tahap tumbuh kembang anak (Laily Hidayati, 2017: 31). Dengan kata lain mendidik anak tidak bergantung pada kuantitas kebersamaan orang tua dengan anak melainkan kualitas pengasuhan itu sendiri.

Anak yang sholih tidak dilahirkan secara alami, melainkan dengan bimbingan dan arahan yang terprogram dan bersifat kontinu. Sebab anak memiliki karakteristik tertentu yang khas dan tidak sama dengan orang dewasa. Mereka selalu aktif, dinamis, antusias serta memiliki rasa keingintahuan yang besar terhadap apa yang ia lihat, dengar dan rasakan (Yuliani Nurani Sudiono, 2011: 6). Mereka akan terus berekplorasi dan belajar untuk menjawab rasa keingintahuannya.

Dalam teori belajar bandura juga dijelaskan bahwa manusia dalam konteks interaksi timbal balik yang berkesinambungan antara kognitif, perilaku dan pengaruh lingkungan (Sugihartono, 2007). Teori bandura ini menunjukkan pentingnya proses mengamati dan meniru perilaku, sikap 
serta reaksi emosi orang lain. Hal inilah yang kemudian menjadi landasan bahwa akhlak tidak bisa diajarkan, melainkan harus ditanamkan melalui proses imitasi dan keteladanan.

Adapun faktor model/keteladanan menurut teori Bandura (Sugiyatno, 2013: 9) memiliki prinsip-prinsip sebagai berikut:

1. Tingkat tertinggi belajar dari pengamatan diperoleh dengan cara mengkonsep perilaku sejak awal kemudian mengulangi perilaku secara simbolik.

2. Individu lebih menyukai perilaku yang ditiru jika sesuai dengan dirinya.

3. Individu akan menyukai perilaku yang ditiru jika model/ panutan tersebut disukai/dihargai dan perilakunya mempunya nilai yang bermanfaat.

Oleh karenanya, orang tua haruslah membiasakan akhlak yang baik pada anak sejak usia dini bahkan sejak dalam kandungan. Pembiasaan-pembiasaan tersebut akan terpatri langsung dalam hati anak. Semakin banyak pembiasaan baik yang dilakukan sejak kecil, semakin baik pula akhlaknya nanti ketika ia dewasa.

Adapun kewajiban orang tua dalam pembinaan akhlak anak menurut Mansur (2009:271) adalah sebagai berikut.

1. Memberi contoh kepada anak dalam berakhlakul karimah atau menjadi suri tauladan yang baik.

2. Memberikan kesempatan pada anak untuk mempraktikkan akhlak mulia dalam keadaan bagaimanapun.

3. Memberi tanggungjawab sesuai dengan perkembangan anak.

4. Mengawasi serta mengarahkan anak dalam pergaulan.

\section{Perkembangan Anak Usia Dini}

Masa anak usia dini merupakan masa-masa emas (the golden ages) dimana seorang anak pada masa tersebut mengalami percepatan hinggan $80 \%$ dari keseluruhan otak orang dewasa. 
Artinya pada masa emas ini anak memiliki kemampuan menyerap segala yang mereka lihat maupun yang didengar. Adapun konsep anak usia dini sendiri, seperti yang dipaparkan oleh Slamet Suyanto, adalah anak yang berusia 0 - 6 tahun. Sedangkan di negara maju anak usia dini adalah anak dengan rentang usia 0 - 8 tahun. Hal ini disebabkan di Indonesia anak usia 7 - 8 tahun sudah memasuki pendidikan sekolah dasar, bukan lagi dalam tatanan pendidikan anak usia dini. Meskipun demikian, dalam memperoleh pendidikan, anak-anak harus tetap mendapatkan perlakuan sebagaimana usianya, sehingga seorang anak tidak kehilangan masa kekanakannya, yang mana pada usia tersebut anak lebih cenderung menyukai bermain sehingga ia merasa bahwa belajar itu menyenangkan.

Pemahaman yang benar tentang bagaimana penyelenggaraan pendidikan anak usia dini hendaknya dimiliki oleh setiap orang yang secara langsung maupun tidak langsung bersentuhan dengan anak. Khususnya adalah orang tua. Seperti yang diungkapkan Nur Cholimah bahwa orang tua cenderung mendidik hanya berdasarkan pengalaman/warisan keluarga. Penanaman yang diberikan oleh guru di sekolah serta yang diberikan orang tua di rumah bisa saja terjadi perbedaan yang menimbulkan ambiguitas pemahaman pada anak. Jika hal ini terjadi, maka akan berakibat kurang baik (setidaknya menimbulkan kebingungan) terhadap perkembangan psikologi anak.

Menurut Nur Cholimah (2012), paling tidak orang tua harus paham dengan karakteriatik anak usia dini, diantaranya :

1. Anak bukan miniatur yang bisa dengan mudah diatur orang dewasa.

2. Anak masih dalam tahap tumbuh kembang.

3. Tumbuh kembang masing-masing anak berbeda.

4. Setiap anak memiliki keunikan.

\section{Penanaman Akhlak di Desa Gesikharjo Palang Tuban}

Penelitian ini dilaksanakan di dusun Gesik desa Gesikharjo RT 002 RW 001. Jenis penelitian yang digunakan adalah 
deskriptif kualitatif dengan pendekatan studi kasus. Menurut Moleong (1993: 165-166) penelitian deskriptif merupakan penelitian yang dimaksudkan untuk mengumpulkan informasi mengenai suatu gejala yang ada. Sedangkan menurut Bogdan dan Taylor (1975: 372) mendefinisikan pendekatan kualitatif sebagai prosedur penelitian yang menghasilkan data deskriptif berupa kata-kata tertulis / lisan dari orang-orang dan perilaku uang diamati.

Informan kunci dalam penelitian ini adalah orang yang terlibat langsung dengan anak yakni orang tua. Subjek penelitian yang dimaksud disini adalah orang tua anak usia 5-6 tahun di dusun Gesik RT 002 RW 001 desa Gesikharjo. Adapun jenis kelamin anak adalah perempuan.

Pengumpulan data dilakukan dengan teknik observasi, wawancara dan dokumentasi. Sedangkan instrumen yang digunakan adalah lembar observasi. Data yang telah diperoleh kemudian dianalisis dengan reduksi data, penyajian data dan kesimpulan. Untuk mendapatkan gambaran pola asuh orang tua di dusun Gesik RT 002 RW 001 desa Gesikharjo, peneliti memilih 3 orang tua anak untuk dilakukan observasi dan wawancara tentang tata cara orang tua yang responsif, ketegasan, tuntutan, pengawasan, keteladanan dan pembiasaan sebagai upaya untuk membangun akhlak anak.

\section{Profil Orang Tua 'Er' dan Pencapaian Sementara akhlak anak}

'Er' merupakan anak pertama dari pasangan ibu KK dan bapak EG. Ayah 'Er' adalah pekerja serabutan sedangkan ibunya sehari-hari menjaga stand toko milik saudaranya. Keduanya masing-masing menamatkan pendidikan ditingkat SMA dan SMP. Meskipun pekerjaan sehari-hari ibu 'Er' menjaga toko, ia berusaha untuk terlibat dalam berbagai aktivitas anak. Misalnya mengantar dan menjemput 'Er' baik saat sekolah maupun saat di TPQ, memeriksa dan menanyakan kembali hal-hal yang dilakukan anak di sekolah, memberikan uang saku secukupnya dengan konsekuensi jika telah habis tidak boleh meminta uang lagi, membiasakan anak menata jadwal 
pelajarannya sendiri, menemani 'Er' belajar. Sedangkan ketika ibu 'Er' menjaga toko, Er dititipkan neneknya. Saat bermain di rumah Er mendapatkan pengawasan dari neneknya, ia tidak berani main jauh dari rumah sendirian tanpa ditemani sang nenek.

Adapun pencapaian sementara akhlak Er adalah, misalnya dalam hal ibadah, ia mampu menghafal surat-surat pendek, do'a sehari-hari dan bacaan-bacaan dalam sholat. Sedangkan dalam tata krama Er mampu menampilkan perilaku sopan dihadapan orang tua, misalnya bilang permisi saat lewat di depan orang yang lebih tua, meminta ijin saat akan bermain. Dalam menjaga kebersihan, Er sering membantu ibunya membersihkan rumah. Dalam hal kedisiplinan, ia akan menangis apabila datang terlambat baik di sekolah maupun $T P Q$, dan marah kepada ibunya apabila merasa tidak dibangunkan lebih awal.

\section{Profil Orang Tua 'Ha' dan Pencapaian Sementara Akhlak Anak}

Ha merupakan anak pertama dari pasangan ibu 'Sr' dan bapak 'Ms'. Kedua orang tua 'Ha' adalah pedagang selama 2 tahun terakhir. Ayah dan ibu 'Ha' sebelumnya bekerja di pabrik wilayah Sidoarjo. Dari usia 0-4 tahun 'Ha' diasuh oleh neneknya. Kedua orang tua 'Ha' menamatkan pendidikan di tingkat SMA. Ayah dan ibu 'Ha'bergantian menjaga stand toko miliknya. Adapun keterlibatan orang tua dalam aktivitas 'Ha'adalah sebagai berikut : mengantar ke sekolah sedangkan waktu pulang 'Ha' dijemput oleh tantenya. Mengantarkan 'Ha' ke TPQ dan tempat les. Memeriksa hasil belajar 'Ha' disekolah dan tempat les tanpa menanyakannya kembali. Memberikan uang saku secukupnya tanpa ada konsekuensinya, apabila habis 'Ha' akan meminta lagi, jika tidak diberi, ia akan merengek terkadang sampai tantrum. Kurang memberikan pengawasan saat 'Ha' bermain diluar rumah. Menyiapkan buku pelajaran 'Ha'.

Adapun pencapaian sementara akhlak 'Ha' adalah dalam hal ibadah misalnya dalam hal ibadah, ia mampu menghafal 
surat-surat pendek dan do'a sehari-hari. Sedangkan dalam tata krama 'Ha' belum mampu menampilkan perilaku sopan dihadapan orang tua, misalnya tidak bilang permisi saat lewat di depan orang yang lebih tua, membentak-bentak orang tua saat keinginannya tidak dipenuhi, dan tidak meminta ijin saat akan bermain. Dalam menjaga kebersihan, 'Ha' sering membantu ibunya membersihkan rumah. Dalam hal kedisiplinan, ia sering datang terlambat saat ke TPQ dan beberapa kali tidak masuk sekolah sebab 'Ha' tidak mau dibangunkan, hal ini disebabkan orang tua 'Ha' tidak akan membangunkannya apabila ia tidur. Apabila dipaksa orang tua merasa mereka nanti repot bila 'Ha' tantrum.

\section{Profil Orang Tua 'Zi' dan Pencapaian Sementara Akhlak Anak}

Zi merupakan anak kedua dari pasangan bapak ' $Q 0$ ' dan ibu 'Yn'. Ayah 'Zi' adalah pekerja bangunan sedangkan ibunya adalah pedagang. Keduanya menamatkan pendidikan ditingkat SMA. Meskipun pekerjaan sehari-hari ibu 'Zi' menjaga toko, ia berusaha untuk terlibat dalam berbagai aktivitas anak. Misalnya mengantar dan menjemput 'Zi' baik saat sekolah maupun saat di TPQ. Memeriksa hal-hal yang dilakukan anak di sekolah. Memberikan uang saku secukupnya, namun jika uang tersebut habis, ibu 'Zi' akan memberinya lagi. Membiasakan anak menata jadwal pelajarannya sendiri. Menyuruh 'Zi' belajar ditempat les. Sedangkan ketika ibu 'Zi' menjaga toko, Zi lebih banyak bermain dengan teman-teman tanpa ada pengawasan dari orang tua.

Adapun pencapaian sementara akhlak Zi adalah, misalnya dalam hal ibadah, ia mampu menghafal surat-surat pendek, do'a sehari-hari dan bacaan-bacaan dalam sholat. Sedangkan dalam tata krama Zi belum mampu menampilkan perilaku sopan dihadapan orang tua, misalnya tidak bilang permisi saat lewat di depan orang yang lebih tua, tidak meminta ijin saat akan bermain. Dalam menjaga kebersihan, $\mathrm{Zi}$ jarang membantu ibunya membersihkan rumah, ibu 'Zi' terkesan lebih memanjakan anak-anak mereka, hal ini terlihat dalam 
pemenuhan kebutuhan anak selalu dituruti. Dalam hal kedisiplinan, ia beberapa kali terlambat masuk TPQ sebab ia masih bermain.

Pendidikan akhlak yang pertama dan utama bagi anak adalah dalam lingkup keluarga. Melalui keluarga, anak akan mempelajari dasar-dasar perilaku yang bisa dijadikan pedoman ketika mereka dewasa. Oleh karenanya eksistensi keluarga dalam membentuk akhlak anak sangatlah diperlukan.

Dari hasil observasi yang didapat oleh peneliti di dusun Gesik desa Gesikharjo RT/RW 002/002 bahwa orang tua yang sering terlibat dalam aktivitas anak mampu membentuk akhlak anak, terutama mampu berperilaku sopan dengan orang lain. Terlibat dalam aktivitas anak yang dimaksud disini bukanlah selalu mendampingi anak kemanapun mereka pergi, melainkan memberikan teladan, pembiasaan, dan tanggungjawab kepada mereka.

Fakta di lapangan menunjukkan bahwa ada dua faktor yang mempengaruhi akhlak anak. Yaitu kualitas kebersamaan orang tua bersama anak dan pola asuh orang tua. Dari hasil observasi diketahui bahwa orang tua yang mampu mengisi waktu dengan baik bersama anak menghasilkan perilaku anak yang lebih baik daripada perilaku anak dengan orang tua yang kurang mampu menjaga kualitas kebersamaan dengan anak. Begitu juga dengan pola asuh, berbeda pola asuh akan menghasilkan output berupa akhlak anak yang berbeda pula.

Kualitas kebersamaan orang tua dengan anak mengacu pada nilai stimulasi tumbuh kembang yang diberikan orang tua kepada anak dalam waktu-waktu kebersamannya (Laily Hidayati, 2017: 30). Dari hasil observasi, mayoritas orang tua di dusun Gesik desa Gesikharjo RT/RW 002/002 adalah pedagang. Adapun kualitas kebersamaan orang tua dengan anak ditunjukkan dengan adanya keterlibatan orang tua dalam aktivitas anak. Seperti membimbing anak saat belajar, menanyakan kembali hal-hal yang telah dipelajari atau kegiatan anak saat di sekolah, TPQ, maupun tempat les. Sedangkan dalam pola asuh, orang tua di dusun Gesik RT/RW 
002/002 menerapkan dua jenis pola asuh, yakni pola asuh permisif, dimana orang tua tidak memberikan batasan dan cenderung memberikan kebebasan pada anak. System reward dan punishment tidak berlaku efektif. Seperti saat orang tua lebih baik memberikan tambahan uang saku pada anak daripada melihat mereka menangis, tidak membangunkan anak pada saat jam sekolah atau mengaji. Yang kedua pola asuh demokratis yang lebih menekankan pada sikap disiplin dan tanggungjawab. Seperti menanyakan kembali hal-hal yang dialami anak, hal ini dapat melatih anak untuk bertanggungjawab dengan segala aktivitasnya.

Berdasarkan beberapa temuan lapangan diatas dapat disimpulkan bahwa dalam membentuk akhlak anak, orang tua banyak memiliki peran diantaranya :

1. Memberikan teladan

2. Membiasakan anak dengan hal-hal yang baik

3. Terlibat dalam aktivitas anak

4. Menanyakan kembali hal-hal yang telah dipelajari dan kegiatan anak selama tidak bersama dengan orang tua

5. Melakukan pengawasan kepada anak saat sedang bermain

6. Menumbuhkan sikap disiplin dan tanggungjawab pada anak.

\section{KESIMPULAN}

1. Pengaruh orang tua sangat besar dalam membentuk kepribadian anak. Sebab keteladanan dari mereka mampu melahirkan pribadi-pribadi yang berakhlakul karimah.

2. Orang tua di dusun Gesik desa Gesikharjo RT/RW 002/002 memiliki kualitas kebersamaan dengan anak yang beragam. kualitas kebersamaan tidak ditentukan dari seberapa lama orang tua bersama-sama dengan anak, akan tetapi lebih pada nilai stimulus yang diberikan orang tua saat bersama anak. Adapun kualitas kebersamaan yang paling menonjol ditunjukkan oleh ibu 'Er', ia mampu membagi waktunya antara pekerjaan dan 
tanggungjawabnya terhadap anak.

3. Orang tua di dusun Gesik desa Gesikharjo RT/RW 002/002 memiliki perlakuan yang berbeda, yakni ada yang menerapkan pola asuh permisif dan ada yang menerapkan pola asuh demokratis. Dari hasil identifikasi ditemukan bahwa anak mampu berakhlakul karimah dari orang tua yang menerapkan pola asuh demokratis.

\section{DAFTAR PUSTAKA}

Bogdan, Robert C dan Stevan J Taylor. Introduction to Qualitative Methods Research, A Phenomenological Approacch to Social Sciences, New York:John Willey \& Son, 1975.

Cholimah, Nur. "Upaya Peningkatan Partisipasi Orang Tua dan Kualitas Pendidik Pada Pendidikan Anak Usia Dini" dalam Jurnal Cakrawala Dini Vol. 9, No.1 Mei 2012

Ghazali, Imam. Ihya' Ulumuddin, Beirut: Dar al-Fikr.

Hidayati, Laily. Asah, Asuh, Asih: Dual-Career Family, Yogyakarta: Program Studi PGRA, 2017.

Mansur. Pendidikan Anak Usia Dini, Yogyakarta: Pustaka Pelajar, 2009.

Maskawaih, Ibnu. Tahzib al akhlaq wa Tathhir A'ro, Cairo: Muassasat al Khariji, 1934.

Moleong, Lexy J. Metodologi Penelitian Kualitatif, Bandung: Remaja Rosdakarya, 1993.

Padjrin, "Pola Asuh Anak dalam Perspektif Pendidikan Islam" dalam Jurnal Intelektualita Vol. 05, No. 01 (2016), 5

Sudiono, Yuliani Nurani. Konsep Pendidikan Anak Usia Dini, Jakarta: PT. Indeks, 2011.

Sugihartono. Psikologi Pendidikan, Yogyakarta: UNY Press, 2007. 
NUR LAILATUL FITRI

Sugiyatno, "Optimalisasi Peran Keluarga dalam Membangun Moral Remaja". Disampaikan dalam rangka kegiatan MOS Maguwoharjo UNY 2013.

Suyanto, Slamet. Dasar-dasar Pendidikan Anak Usia Dini, Yogyakarta: Hikayat, 2005. 